UDC 614.44+616.9-036

DOI: $10.21668 /$ health.risk/2021.2.09.eng

Research article

\title{
DETECTING AND PREDICTING RISKS RELAYED TO SPREAD OF NATURAL FOCI INFECTIONS ON FLOOD-AFFECTED TERRITORIES IN IRKUTSK REGION
}

\author{
N.V. Breneva ${ }^{1}$, S.V. Balakhonov ${ }^{1}$, A.Ya. Nikitin ${ }^{1}$, I.V. Meltsov ${ }^{2}$, M.B. Sharakshanov ${ }^{1}$, \\ V.V. Kuzmenkov ${ }^{1}$, E.A. Sidorova ${ }^{1}$, A.V. Sevostyanova ${ }^{1}$, E.S. Kulikalova ${ }^{1}$, A.V. Mazepa ${ }^{1}$, \\ V.T. Klimov ${ }^{1}$, M.V. Chesnokova ${ }^{1}$, N.V. Ustinova ${ }^{3}$, A.F. Timoshenko ${ }^{3}$, S.A. Borisov ${ }^{1}$, \\ E.A. Basov ${ }^{1}$, N.L. Barannikova ${ }^{1}$, M.I. Tolmachyova ${ }^{1}$, S.E. Ryabtsovskaya ${ }^{1}$, E.I. Andaev ${ }^{1}$ \\ ${ }^{1}$ Irkutsk Antiplague Research Institute of Siberia and Far East awarded by the Labour Red Banner, \\ 78 Trilissera Str., Irkutsk, 664047, Russian Federation \\ ${ }^{2}$ Irkutsk State Agrarian University named after A.A. Ezhevsky, 1/1 Molodezhny settlement, Irkutsk district, \\ Irkutsk region, 664038, Russian Federation \\ ${ }^{3}$ Center for Hygiene and Epidemiology in Irkutsk Region, 51 Trilissera Str., Irkutsk, 664047, Russian Federation
}

(c) Breneva N.V., Balakhonov S.V., Nikitin A.Ya., Meltsov I.V., Sharakshanov M.B., Kuzmenkov V.V., Sidorova E.A., Sevostyanova A.V., Kulikalova E.S., Mazepa A.V., Klimov V.T., Chesnokova M.V., Ustinova N.V., Timoshenko A.F., Borisov S.A., Basov E.A., Barannikova N.L., Tolmachyova M.I., Ryabtsovskaya S.E., Andaev E.I., 2021

Natalia V. Breneva - Candidate of Medical Science, Leading researcher at the Epidemiology Department (e-mail: nbreneva@list.ru; tel.: +7 (395) 222-01-43; ORCID: https://orcid.org/0000-0002-9207-7536).

Sergey V. Balakhonov - Doctor of Medical Sciences, Professor, Director (e-mail: adm@chumin.irkutsk.ru; tel.: +7 (395) 222-01-35; ORCID: https://orcid.org/0000-0003-4201-5828).

Aleksey Ya. Nikitin - Doctor of Biological Sciences, Leading researcher at the Zoological and Parasitological Department (e-mail: nikitin_irk@mail.ru; tel.: +7 (395) 222-01-37; ORCID: https://orcid.org/0000-0002-3918-7832).

Ivan V. Meltsov - Candidate of Veterinary Sciences, Associate Professor (e-mail: ivanmeltsov@mai.ru; tel.: +7 (3952) 23-73-30; ORCID: https://orcid.org/0000-0001-8566-7004).

Munko B. Sharakshanov - Epidemiologist at the Department for Sanitary Territorial Protection and Emergency Monitoring (e-mail: adm@chumin.irkutsk.ru; tel.: +7 (904) 146-30-36; ORCID: https://orcid.org/0000-0002-1114-1795).

Vladimir V. Kuzmenkov - Master of Biology, Laboratory researcher at the Zoological and Parasitological Department (e-mail: Barada.93@mail.ru; tel.: +7 (964) 267-66-08; ORCID: https://orcid.org/0000-0003-3394-5038).

Elena A. Sidorova - Virologist at the Natural Foci Viral Infections Laboratory (e-mail: sidorovavirusolog@yandex.ru; tel.: +7 (395) 222-01-39 (ext. 229); ORCID: https://orcid.org/0000-0003-0279-5831).

Anna V. Sevostyanova - Virologist at the Natural Foci Viral Infections Laboratory (e-mail: annasevost@mail.ru; tel.: +7 (395) 222-01-39 (ext. 229); ORCID: https://orcid.org/0000-0002-3977-8472).

Elena S. Kulikalova - Candidate of Medical Sciences, Head of the Epidemiology Department (e-mail: adm@chumin.irkutsk.ru; tel.: +7 (395) 222-01-43; ORCID: https://orcid.org/0000-0001-7034-5125).

Andrej V. Mazepa - Candidate of Medical Sciences, Leading researcher at the Epidemiology Department (e-mail: amazepa@list.ru; tel.: +7 (395) 222-01-43; ORCID: https://orcid.org/0000-0002-0843-4757).

Valery T. Klimov - Candidate of Medical Sciences, Senior researcher at the Epidemiology Department (e-mail: 41klimov@mail.ru; tel.: +7 (395) 222-01-43; ORCID: https://orcid.org/0000-0003-0036-0017).

Margarita V. Chesnokova - Doctor of Medical Sciences, Professor, Head of the Department for Scientific and Methodical Support (e-mail: adm@chumin.irkutsk.ru; tel.: +7 (395) 222-01-35; ORCID: https://orcid.org/0000-0001-5489-9363).

Natal'ya V. Ustinova - Deputy to Chief Physician (e-mail: Ustinova@sesoirk.Irkutsk.ru; tel.: +7 (395) 222-82-04; ORCID: https://orcid.org/0000-0001-8349-0508).

Alexander F. Timoshenko - Zoologist (e-mail: ilim19@yandex.ru; tel.: +7 (395) 222-82-04; ORCID: https://orcid.org/0000-0003-1503-1857).

Sergey A. Borisov - Laboratory researcher at the Zoological and Parasitological Department (e-mail: adm@chumin.irkutsk.ru; tel.: +7 (395) 222-01-37; ORCID: https://orcid.org/0000-0003-1781-0846).

Evgenii A. Basov - Bacteriologist at the Quality Provision Department (e-mail: adm@chumin.irkutsk.ru; tel.: +7 (395) 223-99-85; ORCID: https://orcid.org/0000-0002-8358-2880). 
Natal'ya L. Barannikova - Candidate of Medical Sciences, Bacteriologist at the Epidemiology Department (e-mail: adm@chumin.irkutsk.ru; tel.: +7 (395) 222-01-38; ORCID: https://orcid.org/0000-0002-5471-2164).

Mary I. Tolmachyova - Researcher at the Epidemiology Department (e-mail: maxa121@mail.ru; tel.: +7 (395) 222-01-43; ORCID: https://orcid.org/0000-0002-4734-0788).

Sof'ya E. Ryabtsovskaya - Laboratory researcher at the Epidemiology Department (e-mail: inst.4ever.youu@yandex.ru; tel.: +7 (395) 222-01-43; ORCID: https://orcid.org/0000-0003-3588-8145).

Evgeni I. Andaev - Deputy Director responsible for general issues and organizational and methodical tasks (e-mail: e.andaev@gmail.com; tel.: +7 (395) 222-00-70; ORCID: https://orcid.org/0000-0002-6612-479x).

In summer 2019 in western Irkutsk region abundant and long rainfall caused a catastrophic flood that became a federal emergency.

It resulted in a threat that natural infection foci would be activated in that emergency zone; given that, the Irkutsk Anti-plague Institute, together with Rospotrebnadzor territorial offices and regional veterinary authorities, conducted an epizootologic-epidemiologic study on affected territories in order to detect and predict possible epidemiologic risks.

Totally, the study covered 30 socially significant objects and natural biotopes in three municipal districts in the region. We tested blood serum of people (244 samples), farm and home animals (253), and organs taken from caught small mammals aiming at determining natural foci infections in them with bacteriologic, serologic, and PCR procedures; overall. 4,370 examinations were performed.

Share of immune people amounted to $13.1 \%$ regarding tularemia; $17.5 \%$, tick-borne encephalitis; yersiniosis, $10.8 \%$; leptospirosis, $3.1 \%$; tick-borne borreliosis, $7.1 \%$. Antibodies to pathogenic leptospira were detected in 36.0-81.3 \% farm animals and it can indicate there is a latent epizootic process. In July 2019 there was low population of synanthropic rodents in socially significant objects on affected territories and small mammals population also decreased in natural foci with high contagion rate for tularemia agent (down to $17.9 \%$ ). In September 2019 rats were detected to inhabit food-related objects and small mammals migrated actively in natural stations, contagion rate with tularemia agent going down among them whereas there was a growth in contagion rate with leptospira (up to $40.0 \%$ ). We also revealed new natural tularemia and leptospirosis foci.

Activity in natural infections foci didn't exceed long-term average level just after the flood; still, there are persisting risks on affected territories in Irkutsk region that an epidemiologic situation might get worse there. The paper contains recommendations on further epizootologic-epidemiologic monitoring and organizing prevention activities such as control over sanitary situation at socially significant objects, local deratization, and sanitation in natural foci of animal leptospirosis.

Key words: emergency, flood, epidemiologic risks, natural foci infections, zoonosis, leptospirosis, tularemia, Irkutsk region.

At the end of the XX and beginning of the XXI century, a number of floods increased worldwide and their destructive force and inflicted economic loss also grew considerably. In Russia, annually more than 50 thousand square kilometers are exposed to flooding. The threat of flooding exists for more than 300 cities, dozens of thousands of other settlements, and industrial enterprises [1]. So, the main task that is to be solved by Rospotrebnadzor, medical and veterinary services on territories that suffered from flooding is to provide sanitary well-being based on epidemiological risk assessment for appropriate responding to a deteriorating sanitary situation [2].

Over the last decade experts at the Irkutsk Antiplague Research Institute have accumulated considerable experience in providing sanitary-epidemiological well-being in emergency zones including those that occurred due to floods in Amur region, Khabarovsk region and Jewish Autonomous Area in 2013; in the Republic of Khakassia and the Altai Republic in 2014 [2, 3]. The same situa- tion connected with abnormal hydrometeorological conditions was observed in Irkutsk region in summer 2019.

On June 25, 2019 water-level started to grow in Angara river feeders after abundant and long rainfall in the western Irkutsk region. In the morning on June 27 six settlements of Nizhneudinsky and Taishetsky district were already underflooded, in the evening of the same day another nine settlements of Tulunsky district [4]. On June 28, 20 settlements were impacted by the flood, more than 800 people were evacuated from their homes, and 17 places of temporary accommodation were organized with a total capacity of 6,500 places; also the federal road R-255 to Tulun was closed for the traffic $[5,6]$. In the morning of June 2931 settlements in Nizhneudinsky, Taishetsky, Tulunsky and Chunsky districts were underflooded. To the noon of the same day, the extremely high water level of the Ia river was 13.8 meters whereas its critically permissible limit was only 7 meters. On June 30,28 settlements remained underflooded in 
the Nizhneudisky, Chunsky, Taishetsky, Tulunsky and Ziminsky districts $[4,6]$.That situation was announced to be a federal emergency by the RF Presidential Order ${ }^{1}$.

About 10.9 thousand houses in 109 settlements where 42.7 thousand people lived were flooded during the $1^{\text {st }}$ flood wave. During the second wave (in late July - early August), 1.9 thousand houses with 5.4 thousand people living there were flooded in 58 settlements. Totally 49 sections of highways and 22 local road bridges were damaged. The stream of water demolished 1.3 thousand houses; almost more than 7 thousand buildings were damaged and could not be restored. 26 people were killed, 4 people were gone missing [7].

The rapid development of the flood situation in Irkutsk region at the beginning of July 2019, a sharp deterioration in the living conditions of the affected population, insufficient provision of high-quality drinking water, an increased number of contacts people had with livestock and wild animals that died from the flood in private farmsteads and natural stations resulted in risks related to epidemic manifestations of acute infectious diseases, including natural focal ones and those common for humans and animals. The experience gained by sanitary anti-epidemic teams (SAET) from the Irkutsk Antiplague Research Institute during the flood in the Amur region in 2013 showed the effectiveness of timely accomplished preventive measures aimed at preventing complications of the epidemiological situation [2].

By the order signed by the Head of the Federal Service for Surveillance on Consumer Rights Protection and Human Wellbeing (Rospotrebnadzor), an emergency operations center was created at the Irkutsk Antiplague Research Institute of Rospotrebnadzor to promptly respond to a worsening flood situation and to coordinate the activities performed by SAET with other services. Previously, we considered its algorithm for taking actions and making organizational decisions [8].
Our research goal was to analyze the data obtained via an epizootologic and epidemiological survey on the flood-affected territories in Irkutsk region, carried out by the operations group of the Irkutsk Antiplague Research Institute in cooperation with the Rospotrebnadzor's territorial bodies and institutions, healthcare and veterinary organizations.

Data and methods. Given the existing situation, the Irkutsk Antiplague Research Institute prepared and conducted two visits by the operation group in July-September 2019 to assess the epidemiological situation with natural focal infectious diseases in the emergency zone in the Irkutsk region that occurred due to a catastrophic summer flood.

The initial phase of work (July 01, 2019 July 12, 2019) in the emergency zone was carried out immediately after the first flood wave, when many areas were still flooded. The second stage (September 18, 2019 - September $28,2019)$ was performed when all affected areas, except for the Chunsky district, were freed from flooding.

The retrospective analysis of the epizootological and epidemiological situation was based on the materials provided by the Reference Center for Monitoring over Natural Focal Diseases (since 2018 - the Scientific and Methodological Center for Monitoring over II-IV Risk Group Pathogens) of the Irkutsk Antiplague Research Institute, archive data and reports issued by Rospotrebnadzor Office in the Irkutsk region, Center for Hygiene and Epidemiology in Irkutsk region, and veterinary stations in Irkutsk region. The operational analysis of the situation was carried out basing on information from territorial institutions and departments, as well as their data obtained during the survey performed in the areas affected by the flood.

Sanitary situation at 30 socially significant objects was assessed as per their population with synanthropic rodents via visual observation and use of control-track sites (CTS),

\footnotetext{
${ }^{1}$ On activities aimed at eliminating consequences of the flood in Irkutsk region: The RF President Order dated July 3, 2019 No. 316 (with alterations made on August 2, 2019). KODEKS: an electronic fund for legal and reference documentation. Available at: https://docs.cntd.ru/document/560536767 (March 03, 2021).
} 
Gero break-back traps and steel traps. The abundance of small mammals $(\mathrm{s} / \mathrm{m})$ in natural stations was tracked as per a number of animals per 100 trap-days ( $\mathrm{t} / \mathrm{d}$ ) using Gero breakback traps. The definition of $\mathrm{s} / \mathrm{m}$ species was given in accordance with descriptions in the monographs $[9,10]$

Blood sampling from the population was carried out in conformity with the decision made by the emergency operations center of the territorial healthcare institutions.

Obtained samples $(n=4,370)$ were examined at laboratories in the Irkutsk Antiplague Research Institute. Blood serum and small mammals' organs were frozen and stored at the temperature $20^{\circ} \mathrm{C}$ below zero, the filter paper was juiced with small mammals' blood, dried and stored at $4-8{ }^{\circ} \mathrm{C}$. Before the examination, the small mammals' organs were thawed and suspensions were prepared with a Tissue Lyser LT homogenizer (Qiagen, Germany).

A random sampling made up of 244 blood serum samples taken from people living in Irkutsk region were examined to detect specific antibodies (IgG, IgA and agglutinins) to infectious agents causing tularemia, leptospirosis, hemorrhagic fever with renal syndrome (HFRS), tick-borne viral encephalitis (TBE), tick-borne borreliosis (ITB), West Nile fever (WNF), brucellosis, and yersiniosis. 222 samples out of them were obtained from the state-funded healthcare facility "Nizhneudinsk community hospital" (Nizhneudinsky district); 22 samples, from a branch of the Center for Hygiene and Epidemiology in Irkutsk Region in Tulunsky and Kuytunsky districts (Tulun city).

195 bovine blood serum samples were obtained from regional state-funded institutions including animal health centers in Nizhneudinsky district (66), Taishetsky district (99), and Tulun city (30); 32 small cattle blood serum samples were obtained from Nizhneudinsky district; 22 samples from horses, from Nizhneudinsky district (18) and Taishetsky district (4); 4 blood serum samples from dogs from Nizhneudinsk. All the samples were examined to detect specific antibodies to causative agents of leptospirosis and brucellosis.
Organs (kidneys, spleen, lungs, and brains) and blood of 237 captured small mammals (205, Nizhneudinsky district; 15, Taishetsky district; and 17, Tulunsky district) were tested to detect antibodies to causative agents of tularemia, leptospirosis, TBE, tularemia antigen, DNA of tularemia, leptospirosis causative agents, TBE virus antigen and RNA of the WNF virus and hantaviruses. Intestine samples of 69 small mammals (52 from Nizhneudinsky district and 17 from Tulunsky district) were investigated for yersiniosis via bacteriologic procedures and PCR; six combined spleen samples were investigated for tularemia via biological procedures using outbred white mice.

Anti-tularemia antibodies were determined in human serum and small mammals blood using the "RNGA-Tul-Ag-StavNIPCHI" (StavNIPCHI, Stavropol) and chromatic tularemia diagnosticum (Irkutsk Antiplague Research Institute) for agglutination micro response (MRA). Tularemia antigen in spleen suspensions of small mammals was detected using "RNGA-Tul-IgStavNIPCHI" (StavNIPCHI, Stavropol).

Anti-leptospirosis agglutinins in all serum and blood taken from small mammals were detected by MAT (Microscopic Agglutination Test) with a set of 11 reference leptospira strains; immunoglobulin, using "LeptospirosisELISA-IgG", "Leptospirosis-ELISA-IgA" test systems ("Omniks", St. Petersburg).

IgG to hemorrhagic fever with renal syndrome, tick-borne encephalitis, tick-borne borreliosis in samples from humans were detected via using "LymeBest-IgG", "VectoTBEV-IgG", "VectoHanta-IgG" test-systems; IgG to pathogenic Yersinia, using "YersiniaIgG-EIA-BEST" test-system ("VECTORBEST", Novosibirsk).

Antigens to TBE and WNF in small mammals' brains were detected via immunofluorescence assay using ELISA reagent kit for detecting antigens to tick-borne encephalitis in field samples and ELISA reagent kit for detecting antigens to West Nile virus in field samples ("Bioservice", Moscow).

Nucleic acid extraction was made with "RIBO-prep", nucleic acid in pathogenic lep- 
tospira was detected via real-time PCR with “AmpliSens ${ }^{\circledR}$ Leptospira-FRT" test-system. Pathogenic yersinia were detected with "AmpliSens ${ }^{\circledR}$ Yersinia enterocolitica / Y.pseudotuberculosis - FRT" PCR kit; West-Nile Fever virus was detected with “ AmpliSens ${ }^{\circledR}$ WNV-FRT" ("InterLabService", Moscow); tularemia causative agent was detected with PCR kit "Gen Francisellatularensis - RGF» (RusRAPI "Microbe") using Rotor-GeneQ amplifier (Qiagen, Germany). Hantavirus DNA was detected via using "Reverta-L" detection kit ("InterLabService", Moscow). PCR was performed with using primers that encode L-exon in hanta-virus [11] with CFX96 (BioRad, USA); all results were accounted for via agarose gel electrophoresis. Positive samples were sequenced with "ABIPrism" 3500XL (Applied Biosystems / Hitachi, Japan) using Big Dye Terminator Cycle Sequencing Kit v 1.1 (Applied Biosystems, USA) to define hantavirus genotype. Nucleotide sequence was processed with Bio Edit program V.7.0.9 [12].

All obtained results were statistically processed with standard variation statistics procedures with calculating arithmetic mean values and their error, as well as via comparing individual samples using Student's t-test for qualitative features [13].

Results and discussion. Retrospective analysis of the epidemiological situation in the flood zone showed that natural foci of tularemia and leptospirosis occurred in Nizhneudinsky district. Thus, in 1937 an outbreak of tularemia was registered here; and in 1994, an outbreak of leptospirosis [14]. Natural infection foci are very stable and can exist for decades without showing themselves in any way [15]; therefore, in 2012-2014 a planned survey of the natural foci in Nizhneudinsky district was performed and the results indicated their activity was low [14]. Over five years preceding the flood, focal diseases of tularemia and leptospirosis were not registered on the territories in the emergency zone; no unfavorable events with farm animals were detected. The last cases of brucellosis in cattle, small cattle and horses were registered in Irkutsk region in 2004-2011 [16]. In general, the epidemiological and epizootic situation was safe in Irkutsk region before the flood ${ }^{2}[17]$.

The laboratory base used by the operation group at the Irkutsk Antiplague Institute was organized in the building where the veterinary laboratory of "Nizhneudinsky district animal health center", the regional state-funded institution, was located. It was flooded during the first wave, but quickly restored its work and performed all the tasks assigned to the Veterinary Service in Irkutsk Region to eliminate the consequences of emergency. First of all, all dead animals' corpses were collected and destroyed. According to operational data as on August 28, 2019 4,736 corpses were collected in the emergency zone; poultry accounted for the biggest share (3,113 corpses); small domestic animals followed (rabbits, 885; dogs and cats, 250); and large farm animals were the next (cattle, 115; small cattle, 103; pigs, 260; horses, 10). In Tulunsky district, about three thousand animal corpses were collected; in Nizhneudinsky district, about a thousand. All dead animals were burned in specially prepared places. The veterinary service also took necessary actions to catch, treat, vaccinate and provide temporary keeping for neglected small animals. During the emergency period, 744 animals were caught; in Chunsky district, 175; Taishetsky, 90; Nizhneudinsky, 123; across Tulun and Tulunsky district, 356. 7,349 animals were vaccinated against rabies. Ultimate disinfection was provided for livestock buildings and walking yards, livestock enterprises and personal subsidiary farms affected by the flood. Overall, 913 objects were disinfected in a total area being equal to 165,948 square meters. Deratization was carried out at 263 objects $(73,419$ square meters). We emphasize that all veterinary care provided during the period of flood for private appeals was free of charge.

The tasks performed by the operation group at the Irkutsk Antiplague Institute in-

\footnotetext{
${ }^{2}$ On the sanitary-epidemiologic situation and prevetive and anti-epidemic activities being accomplished in the zone of underflooding. Rospotrebnadzor Regional office in Irkutsk region, 2019. Available at: http://38.rospotrebnadzor.ru/ (November 25, 2020).
} 
cluded an epizootologic and epidemiological examination, analysis of the epidemiological situation and forecasting its changes, as well as preventive work with the population and the development of guidelines on how to reduce risks that the epidemiological situation would deteriorate.

Particular attention was paid to examining socially significant facilities (places of temporary accommodation, food facilities, schools, and kindergartens), which provided the affected population with necessary services. It was important to prevent small mammals and rodents from penetrating into these objects and timely take preventive measures. A total of 549 break-back traps were installed, and $5.8 \pm 1.0 \%$ of them turned out to be tracked. At socially significant objects, 168 traps per day were worked out, $6.5 \pm 1.9 \%$ of hits of synanthropic rodents were detected. The presence of rodents was established at six sites (see Table 1), and their supervisors were recommended to immediately carry out unscheduled deratization.

Data on a share of population being immune to tularemia, TBE, yersiniosis, leptospirosis and borreliosis are given in Table 2. In
Shumsky settlement in Nizhneudinsky district, people were identified who responded positively to brucellosis. In two cases also antibodies to Hantavirus were detected; this seems important since Irkutsk region is considered non-endemic as per HFRS [18, 19]. High immune layer to tularemia that amounted to $17.5 \pm 4.2 \%$ in Shumsky settlement where this disease was not previously registered and the population was not covered by preventive immunization could indicate a recent contact that people had with the infection in natural sites and thus an existing natural focus.

Epizootologic survey of natural biotopes involved working out a total of 2,080 trapdays. The abundance of small mammals was $11.4 \pm 0.7 \%$ of hits. In July the East Asian mice prevailed in the capture in the vicinity of Shumsky settlement $(83.3 \pm 6.8 \%)$ and they had previously been very rare there (2012, $3.5 \pm 2.0 \% ; p<0.01)$. Laboratory studies revealed a high infection of small mammals by the causative agent of tularemia and relatively low infection by leptospira, which was also uncharacteristic for this area in 2012-2014 (see Table 3).

Table 1

Socially significant facilities with detected rodent presence

\begin{tabular}{|c|c|c|c|c|}
\hline № & Facility & Date & Survey method & Results \\
\hline \multicolumn{5}{|c|}{ July 2019} \\
\hline 1. & $\begin{array}{c}\text { "Boarding school No. 26" Rus- } \\
\text { sian Railways affiliate, place of } \\
\text { temporary accommodation in } \\
\text { Nizhneudinsk }\end{array}$ & $\begin{array}{l}\text { July } 03-04, \\
2019\end{array}$ & $\begin{array}{l}43 \text { control-track sites, } \\
\text { visual observation }\end{array}$ & $\begin{array}{c}9.3 \% \text { of control-track site } \\
\text { tracked (mice), one rat corpse } \\
\text { found }\end{array}$ \\
\hline 2. & $\begin{array}{c}\text { Confectionary factory "Siberia”, } \\
\text { Nizhneudinsk }\end{array}$ & $\begin{array}{c}\text { July 06-07, } \\
2019\end{array}$ & $\begin{array}{l}50 \text { control-track sites, } \\
\text { visual observation }\end{array}$ & $\begin{array}{l}4.0 \% \text { of control-track site } \\
\text { tracked (mice) }\end{array}$ \\
\hline 3. & $\begin{array}{l}\text { Shumsky municipal hospital, } \\
\text { Shumsky }\end{array}$ & $\begin{array}{c}\text { July } 02-03, \\
2019 \\
\end{array}$ & $\begin{array}{c}30 \text { control-track sites, } \\
\text { visual observation }\end{array}$ & $\begin{array}{l}6.7 \% \text { of control-track site } \\
\text { tracked (mice) }\end{array}$ \\
\hline \multicolumn{5}{|c|}{ September 2019} \\
\hline 4. & $\begin{array}{c}\text { Tulun Grain delivery station, } \\
\text { Tulun }\end{array}$ & $\begin{array}{l}\text { September } 17-18 \text {, } \\
2019\end{array}$ & $\begin{array}{c}8 \text { steel traps; } \\
20 \text { control-track sites, } \\
\text { visual observation }\end{array}$ & $\begin{array}{l}3 \text { grey rats caught; } 100 \% \text { of } \\
\text { control-track sites tracked }\end{array}$ \\
\hline 5. & Taishet bakery complex, Taishet & $\begin{array}{l}\text { September 19-20, } \\
2019\end{array}$ & $\begin{array}{l}20 \text { control-track sites, } \\
\text { visual observation }\end{array}$ & $\begin{array}{l}20.0 \% \text { of control-track sites } \\
\text { tracked; one rat corpse found }\end{array}$ \\
\hline 6. & $\begin{array}{l}\text { Central food market, } \\
\text { Nizhneudinsk }\end{array}$ & $\begin{array}{c}\text { September 26-27, } \\
2019\end{array}$ & $\begin{array}{l}25 \text { break-back traps, } \\
\text { visual observation }\end{array}$ & $\begin{array}{l}0 \text { collected rodents; inhabited } \\
\text { rat burrows found }\end{array}$ \\
\hline
\end{tabular}


Serological screening of the population regarding zoonotic diseases in flood-affected districts in Irkutsk region

\begin{tabular}{|c|c|c|c|}
\hline \multirow{2}{*}{ Infection } & \multirow[t]{2}{*}{ Method } & \multicolumn{2}{|c|}{$\begin{array}{l}\text { Quantity of investigations / } \\
\% \text { of positive results (reaction titer) }\end{array}$} \\
\hline & & July, 2019 & September, 2019 \\
\hline \multirow{3}{*}{ Leptospirosis } & MAT & $94 / \mathbf{2 . 1} \pm 1.5(1: 20)$ & $114 / \mathbf{2 . 6} \pm 1.5(1: 20-100)$ \\
\hline & ELISA, IgG & $130 / \mathbf{3 . 1} \pm 1.5$ & $41 / \mathbf{0}$ \\
\hline & ELISA, IgA & $80 / 0$ & $\mathrm{n} / \mathrm{i}$ \\
\hline Tularemia & RNGA, *MRA & $130 / 13.1 \pm 3.0(1: 20-80)$ & $* 106 / 4.7 \pm 2.1(1: 20)$ \\
\hline HFRS & \multirow{4}{*}{ ELISA, IgG } & $80 / \mathbf{0}$ & $99 / \mathbf{3 . 0} \pm 1.6$ \\
\hline TBE & & $80 / \mathbf{1 7 . 5} \pm 4.2$ & $99 / 9.1 \pm 2.9$ \\
\hline TBB & & $80 / \mathbf{0}$ & $99 / 7.1 \pm 2.4$ \\
\hline Yersiniosis & & $130 / \mathbf{1 0 . 8} \pm 2.7$ & $41 / 9.8 \pm 4.6$ \\
\hline \multirow[b]{2}{*}{ Brucellosis } & ELISA, IgG & $130 / \mathbf{0}$ & $105 / \mathbf{1 . 9} \pm 1.3$ \\
\hline & Heddlson's reaction & $105 / 0$ & $\begin{array}{c}105 / \mathbf{1 . 0} \pm 1.0 \\
(0.04+++; 0.02+++; 0.01+++)\end{array}$ \\
\hline
\end{tabular}

N o t e s : n/i means not investigated;

Description: HFRS is hemorragis fever with renal syndrome; TBE, tick-borne encephalitis; TBB, ixodic tickborne borreliosis; MAT, Microscopic Agglutination Test; * MRA, micro-reaction of agglutination.

Table 3

The results of small mammals' investigation to detect tularemia and leptospira causative agents in the flood-affected districts in Irkutsk region

\begin{tabular}{|c|c|c|c|c|c|}
\hline \multirow{3}{*}{ Survey territory } & \multirow{3}{*}{ Date of survey } & \multicolumn{4}{|c|}{ Totally investigated / positive results (\%) } \\
\hline & & \multicolumn{3}{|c|}{ Tularemia } & Leptospirosis \\
\hline & & $\mathrm{AB}$ & $\mathrm{AG}$ & DNA & DNA/RNA \\
\hline \multirow{3}{*}{$\begin{array}{l}\text { Shumsky municipal } \\
\text { district }\end{array}$} & $2012-2014$ & $53 / \mathbf{1 1 . 3} \pm 4.2$ & $5 * / \mathbf{6 0 . 0} \pm 21.9$ & $\mathrm{n} / \mathrm{i}$ & $105 / \mathbf{1 7 . 1} \pm 3.7$ \\
\hline & July 2019 & $30 / \mathbf{4 0 . 0} \pm 8.9$ & $17 * / 23.5 \pm 10.3$ & $17 * / 5.9 \pm 5.4$ & $30 / \mathbf{3 . 3} \pm 3.3$ \\
\hline & September 2019 & $77 / \mathbf{1 . 3} \pm 0.9$ & $19^{*} / \mathbf{1 0 . 5} \pm 2.3$ & $19 * / \mathbf{0}$ & $77 / \mathbf{6 . 5} \pm 2.8$ \\
\hline \multirow{3}{*}{$\begin{array}{l}\text { Nizhneudinsky district } \\
\text { (including Shumsky } \\
\text { municipal district) }\end{array}$} & $2012-2014$ & $53 / \mathbf{1 1 . 3} \pm 4.2$ & $5^{*} / 60.0 \pm 6.4$ & $\mathrm{n} / \mathrm{i}$ & $105 / \mathbf{1 7 . 1} \pm 3.7$ \\
\hline & July 2019 & $58 / \mathbf{3 1 . 0} \pm 6.1$ & $28 * / 32.1 \pm 8.8$ & $28 * / 17.9 \pm 7.2$ & $61 / \mathbf{1 . 6} \pm 1.6$ \\
\hline & September 2019 & $144 / 1.4 \pm 0.9$ & $46 * / 15.2 \pm 2.7$ & $46 * / 0$ & $144 / \mathbf{1 0 . 4} \pm 5.9$ \\
\hline Tulunsky district & \multirow{2}{*}{ September 2019} & $17 / 5.9 \pm 5.7$ & $6^{*} / \mathbf{1 6 . 7} \pm 9.0$ & $6 * 0$ & $17 / \mathbf{1 7 . 6} \pm 9.2$ \\
\hline Taishetsky district & & $3^{*} / \mathbf{3 3 . 3} \pm 12.2$ & $15 / 0$ & $3^{*} / 0$ & $15 / \mathbf{4 0 . 0} \pm 12.6$ \\
\hline
\end{tabular}

$\mathrm{N}$ o t e : * means combined probes; $\mathrm{n} / \mathrm{i}$, not investigated; $\mathrm{AB}$, antibodies; AG, antigen.

In July 2019, anti-tularemia antibodies were found in more than a third of small mammals captured in the vicinity of Shumsky settlement, which could be a sign of a fading epizooty [2]. High epizootic activity detected in Shumsky municipal district's natural focus of tularemia was confirmed with an immune layer being present among local residents. Detection of antigen and DNA of the tularemia causative agent in small mammals in Nizhneudinsky district, including those which were captured within the city of Nizhneudinsk, indicated a risk that an epizooty would develop further provided there was a sufficient number of susceptible individuals. The situation was aggravated by animals migrating actively and occurring reserves with a high number of blood-sucking mosquitoes in numerous temporary wet biotopes. However, in September 2019, despite an increase in the number of carriers (from $8.8 \pm 1.1$ to $15.4 \pm$ $\pm 1.1 \%$ of hits, $p<0.01$ ), their infection with tularemia causative agent sharply decreased in comparison with July $(p<0.01)$. Also in September, the ratio of small mammals' species changed significantly and approached the levels that were observed in the area in 2012-2014. While exploring the surroundings 
of Shumsky settlement, experts didn't detect any small mammals on the outskirts. In the vicinity of the settlement, as before, animals were concentrated in the reserve stations (hills, forest belts). However, the root vole began to predominate in the catches $(45.4 \pm$ $\pm 5.7 \%$, in $20129.4 \pm 5.4 \%$ ), and the proportion of East Asian mice decreased 2.5 times falling to $31.2 \pm 5.3 \%(p<0.01)$.

In September 2019, seven house mice and one gray rat were captured in the residential sector of Nizhneudinsk. In natural stations on the outskirts of Nizhneudinsk, the root vole $(33.9 \pm 6.2 \%)$ and field mouse $(22.0 \pm$ $\pm 5.4 \%$ ) prevailed in the catches. When examining Taishet district in the flood plain area on the right bank of the Biryusa river, experts detected that shrews and red voles prevailed there $(46.7 \pm 12.9 \%$ each $)$. Their infection with leptospirosis was unexpectedly high, which is consistent with the results obtained via serological screening performed over livestock animals. When examining the outskirts of Tulun in forest-shrub biotope on the left bank of the Ia river, experts didn't find any small mammals. This place was completely submerged in both the first and second flood waves. The surroundings of the Bulushkin settlement were also strongly flooded in the first wave of flood, but the second wave practically did not affect them, and there a high number of small mammals was revealed $(14.0 \pm 3.5 \%$ of hits $)$, mostly shrews $(64.3 \pm 12.8 \%$ of the catch), and their high infection with tularemia and leptospirosis pathogens was confirmed (see Table 4).

Small mammals infected with WNF and TBE viruses were not identified.

RNA of Hantavirus Seewis was detected in samples from Tulunsky and Nizhneudinsky districts and it is consistent with detection of antibodies in humans and is of great scientific interest. The pathogen of tularemia was not isolated in six PCR-positive spleen samples.

The DNA of the pseudotuberculosis and intestinal yersiniosis causative agents was found in $52.2 \pm 6.0 \%$ of the small mammals' kidney samples. Besides, in Nizhneudinsky district experts detected three cultures of Yersinia pseudotuberculosis and five pathogenic Y.enterocolitica belonging to $0: 3$ serovars.

Serological screening of animals revealed a high percentage of cattle that reacted positively with leptospira serogroups Tarassovi and Hebdomadis (see Table 4), in the Tulunsky district in unvaccinated cattle, in addition to Bataviae and Grippotyphosa, and in Nizhneudinsk - Canicola, with the absence of sick animals; it could indicate there was a latent epizootic process. When it comes down to small cattle, the situation is similar to that of

Table 4

The results of livestock animals' serological screening for leptospirosis in Irkutsk region districts affected by flood $(\%)$

\begin{tabular}{|c|c|c|c|c|c|}
\hline \multirow[b]{2}{*}{ Serogroup } & \multirow{2}{*}{$\begin{array}{c}\text { Taishetsky } \\
\text { district } \\
(n=99)\end{array}$} & \multirow{2}{*}{$\begin{array}{c}\text { Tulunsky } \\
\text { district } \\
(n=30)\end{array}$} & \multicolumn{2}{|c|}{ Nizhneudinsky district } & \multirow[b]{2}{*}{$\begin{array}{l}\text { Reaction } \\
\text { titre }\end{array}$} \\
\hline & & & $\begin{array}{c}\text { July } \\
(n=50)\end{array}$ & $\begin{array}{c}\text { September } \\
(n=16)\end{array}$ & \\
\hline Grippotyphosa* & $11.2 \pm 3.2$ & $40.0 \pm 8.9$ & $4.0 \pm 2.8$ & $25.0 \pm 10.8$ & $1: 20-1: 100$ \\
\hline Sejroe* & $17.2 \pm 4.0$ & 0 & 0 & 0 & $1: 20-1: 100$ \\
\hline Tarassovi* & $52.5 \pm 5.0$ & $63.4 \pm 8.8$ & $20.0 \pm 5.6$ & $50.0 \pm 12.5$ & $1: 20-1: 100$ \\
\hline Pomona* & $11.2 \pm 3.2$ & 0 & 0 & $68.8 \pm 11.6$ & $1: 20-1: 100$ \\
\hline Icterohaemorrhagiae & $1.0 \pm 1.0$ & 0 & $4.0 \pm 2.8$ & $12.5 \pm 8.3$ & $1: 20$ \\
\hline Hebdomadis & $17.2 \pm 4.0$ & $10.0 \pm 5.5$ & $6.0 \pm 3.4$ & $18.8 \pm 9.8$ & $1: 20-1: 100$ \\
\hline Javanica & 0 & 0 & 0 & 0 & - \\
\hline Bataviae & $12.1 \pm 3.3$ & $23.4 \pm 7.7$ & $4.0 \pm 2.8$ & $12.5 \pm 8.3$ & $1: 20$ \\
\hline Canicola & $1.0 \pm 1.0$ & 0 & $14.0 \pm 4.9$ & $31.3 \pm 11.6$ & $1: 20-1: 200$ \\
\hline Autumnalis & $5.1 \pm 2.2$ & $3.4 \pm 3.3$ & 0 & $25.0 \pm 10.8$ & $1: 20$ \\
\hline Australis & $1.0 \pm 1.0$ & $3.4 \pm 3.3$ & 0 & $6.25 \pm 1.2$ & $1: 20$ \\
\hline Total \% & $71.2 \pm 4.5$ & $76.7 \pm 7.7$ & $36.0 \pm 6.8$ & $81.3 \pm 9.8$ & $1: 20-1: 200$ \\
\hline
\end{tabular}

$\mathrm{N}$ o t e : means included in vaccine. 
cattle; horses, in addition to all of the above, can become infected with leptospira serogroups Autumnalis $(40.9 \pm 10.5 \%$, titers 1:201:100), Javanica $(36.4 \pm 10.3 \%$, titer $1: 20)$ and Bataviae $(27.3 \pm 9.5 \%$, titer 1:20).

Conclusions. Summing up the results obtained via the epizootologic survey, they can be briefly presented in the following way. After the first wave of flood in July 2019, on the affected territories there was a low population of socially significant objects by rodents (mice) and a number of small mammals was depressed in natural sites with their high infection with tularemia causative agent and low infection with leptospira. In September 2019, there was a high population of rats in some food premises in the cities of Tulun, Taishet and Nizhneudinsk; small mammals quantity recovered in natural sites with a decrease in their infection with the causative agent of tularemia and an increase with leptospira. A natural focus of tularemia was revealed in the vicinity of Shumsky settlement in Nizhneudinsky district. Also it has been established there were of agricultural and natural foci of leptospirosis in Tulunsky and Taishetsky districts.

Sanitary and epidemiological situation on the affected territories remained stable; the levels of infectious morbidity were within the mean long-term values. Group and outbreak morbidity has not been registered [20].

Forecast for natural focal infections and zoonoses is relatively favorable for the coming years for Nizhneudinsky district. Complicated epidemiological situation can be caused by massive reproduction of small mammals, however, but there are no prerequisites for this. Stronger monitoring is needed first to detect the natural focus of tularemia in the vicinity of Shumsky settlement. A situation that is emerging in Tulunsky and Taishetsky districts in connection with previously identified unregistered foci of leptospirosis remains unclear. The detection of antigen and antibodies to hanta viruses requires further examination.

The main preventive measures that need to be carried out basing on the results of the survey include the following: leptospirosis foci of farm animals should be sanitized; control should be performed over socially significant objects with identified violations; further epizootologic and epidemiological monitoring is required. Significant small mammals' infection with pathogenic Yersinia requires intensified preventive measures aimed at excluding animals' contacts with food and drinking water provided for people: local deratization measures in places of small mammals finding, control over rodent population at socially significant objects (primarily those associated with food production and distribution), control over measures taken to ensure rodent impermeability into food objects, strict adherence to the conditions and terms of food products storage, control over water intakes, drinking water quality control.

Thus, we can say that the flood wave extinguished the epizootic process in natural foci, causing a depression in the number of carriers. Biotic communities are being renewed on flood-affected territories in Irkutsk region, small mammals are migrating and inhabiting vacated natural niches, and also new natural foci of tularemia and leptospirosis have been revealed and it means that there are still risks that natural foci infections might spread in the area.

Funding. The research was not granted any financial support.

Conflict of interests. The authors declare there is no any conflict of interests.

\section{References}

1. Vorob'ev Yu.L., Akimov V.A., Sokolov Yu.I. Katastroficheskie navodneniya nachala XXI veka: uroki i vyvody [Catastrophic floods in early $21^{\text {st }}$ century: lessons and conclusions]. Moscow, OOO «DEKS-PRESS» Publ., 2003, 352 p. (in Russian).

2. Obespechenie sanitarno-epidemiologicheskogo blagopoluchiya naseleniya pri likvidatsii posledstvii navodneniya na Dal'nem Vostoke [Providing sanitary-epidemiologic safety of population 
when eliminating consequences of the flood in the Far East]. In: G.G. Onishchenko, S.V. Balakhonova eds. Novosibirsk, Nauka-Tsentr Publ., 2014, 648 p. (in Russian).

3. Noskov A.K., Balakhonov S.V., Mikhailov L.M., Vishnyakov V.A., Kulikalova E.S., Mazepa A.V., Breneva N.V., Sidorova E.A. [et al.]. Epidemiologic situation on zoonotic infectious diseases on the territories of Siberia and far east suffered from natural disasters in 2013-2014. Dal'nevostochnyi zhurnal infektsionnoi patologii, 2016, no. 30, pp. 6-10 (in Russian).

4. Kuznetsova Z. Pavodok v Irkutskoi oblasti. Khronika sobytii [Flood in Irkutsk region: chronicle of events]. Novosti Irkutska i Priangar'ya. Irkutskii portal, 2019. Available at: https://ircity.ru/articles/38418/ (25.11.2020) (in Russian).

5. Svodka ChS GU MChS Rossii po Irkutskoi oblasti na 6-00 28.06.2019 g. [Report on emergences by the Irkutsk Regional Office of EMERCOM of Russia of June 28, 2019, 6.00 a.m.]. Operativnaya informatsiya GU MChS Rossii po Irkutskoi oblasti, 2019. Available at: https://38.mchs.gov.ru/deyatelnost/press-centr/operativnaya-informaciya/svodka-chs-i-proisshestviy/ (25.11.2020) (in Russian).

6. Novosti Irkutska: ekonomika, sport, meditsina, kul'tura [Irkutsk news: economy, sport, public healthcare, and culture]. Tvoi Irkutsk, 2019. Available at: http://www.irk.ru/news/ (25.11.2020) (in Russian).

7. Pavodok v Irkutskoi oblasti [Flood in Irkutsk region]. TASS, 2019. Available at: https:// tass.ru/pavodok-v-irkutskoy-oblasti/ (25.11.2020) (in Russian).

8. Nikitin A.Ya., Noskov A.K., Balakhonov S.V. Taktika organizatsii i provedeniya epizootologo-epidemiologicheskogo monitoringa $\mathrm{v}$ tselyakh obespecheniya biobezopasnosti massovykh meropriyatii i v usloviyakh chrezvychainykh situatsii [Tactics of organizing and accomplishing epizootologic-epidemiologic monitoring aimed at providing biological safety during mass events and in case of emergency]. Zhurnal infektologii, 2015, vol. 7, no. S3, 64 p. (in Russian).

9. Gromov I.M., Erbaeva M.A. Mlekopitayushchie fauny Rossii i sopredel'nykh territorii. Zaitseobraznye i gryzuny [Mammals in Russia and adjoining territories. Lagomorphs and rodents]. Sankt-Peterburg, ZIN RAN Publ., 1995, 540 p. (in Russian).

10. Pavlinov I.Ya., Rossolimo O.L. Sistematika mlekopitayushchikh SSSR: issledovaniya po faune Sovetskogo Soyuza [Taxonomy of mammals in the USSR: studies on fauna in the Soviet Union]. In: V.E. Sokolova ed., 1987, 285 p. (in Russian).

11. Arai S., Bennett S.N., Sumibcay L., Cook J.A., Song J.W., Hope A. Short Report: Phylogenetically Distinct Hantaviruses in the Masked Shrew (Sorex cinereous) and Dusky Shrew (Sorex monticolus) in the United States. Am. J. Trop. Med. Hyg, 2008, vol. 78, no. 2, pp. 348-351. DOI: 10.4269/ajtmh.2008.78.348

12. Hall T.A. Bio Edit: auser-friendly biological sequence alignment editor and analysis program for Windows 95/98/NT. Nucleic Acids Symp, 1999, no. 41, pp. 95-98.

13.Zaks L. Statisticheskoe otsenivanie [Statistic estimation]. In: Yu.P. Adler, V. Gorskii eds. Moscow, Statistika Publ., 1976, 598 p. (in Russian).

14. Kiseleva E.Yu., Breneva N.V., Sharakshanov M.B., Noskov A.K., Borisov S.A., Chesnokova M.V., Balandina T.P., Nursayanova L.P. [et al.]. Actual problems of epidemiological surveillance for leptospirosis in Irkutsk region. Epidemiologiya i vaktsinoprofilaktika, 2014, vol. 77, no. 4, pp. 51-56 (in Russian).

15. Korenberg E.I., Pomelova V.G., Osin N.S. Prirodnoochagovye infektsii, peredayushchiesya iksodovymi kleshchami [Natural foci infections borne by ticks]. In: A.L. Gintsburga, V.N. Zlobina eds. Moscow, Nauka Publ., 2013, 465 p. (in Russian).

16. Ablov A.M., Anganova E.V., Batomunkuev A.S., Trofimov I.G., Baryshnikov P.I., Meltsov I.V. Brucellosis farm animals in the Irkutsk region. Vestnik APK Stavropol'ya, 2015, vol. 20, no. 4, pp. 81-84 (in Russian).

17. Epizooticheskaya situatsiya v RF [Epizootic situation in the RF]. Ofitsial'nyi sait Rossel'khoznadzora. Available at: http://www.fsvps.ru/fsvps/iac/rf/reports.html/_(25.11.2020) (in Russian).

18. Tkachenko E.A., Bernshtein A.D., Dzagurova T.K., Morozov V.G., Slonova R.A., Ivanov L.I., Trankvilevskii D.V., Kryuger D. Actual problems of hemorrhagic fever with renal syndrome. Zhurnal mikrobiologii, epidemiologii i immunobiologii, 2013, no. 1, pp. 51-58 (in Russian). 
19. Slonova R.A., Tkachenko E.A., Ivanis V.A., Kompanets G.G., Dzagurova T.K. Gemorragicheskaya likhoradka s pochechnym sindromom [Hemorrhagic fever with renal syndrome]. Vladivostok, OAO «Primpoligrafkombinat» Publ., 2006, 246 p. (in Russian).

20. O kontrole za epidemiologicheskoi situatsiei v Irkutskoi oblasti v svyazi s pavodkami [On control over epidemiologic situation in Irkutsk region due to flood]. Sait Federal'noi sluzhby po nadzoru $v$ sfere zashchity prav potrebitelei i blagopoluchiya cheloveka, 2019. Available at: https://www.rospotrebnadzor.ru_(25.11.2020) (in Russian).

Breneva N.V., Balakhonov S.V., Nikitin A.Ya., Meltsov I.V., Sharakshanov M.B., Kuzmenkov V.V., Sidorova E.A., Sevostyanova A.V., Kulikalova E.S., Mazepa A.V., Klimov V.T., Chesnokova M.V., Ustinova N.V., Timoshenko A.F., Borisov S.A., Basov E.A., Barannikova N.L., Tolmachyova M.I., Ryabtsovskaya S.E., Andaev E.I. Detecting and predicting risks relayed to spread of natural foci infections on flood-affected territories in Irkutsk region. Health Risk Analysis, 2021, no. 2, pp.94-104. DOI: 10.21668/health.risk/2021.2.09.eng

Received: 25.03 .2021

Accepted: 07.06.2021

Published: 30.09.2021 